\title{
Die positivering van geborgenheid met die oog op 'n meer gedissiplineerde onderrig-leeromgewing
}

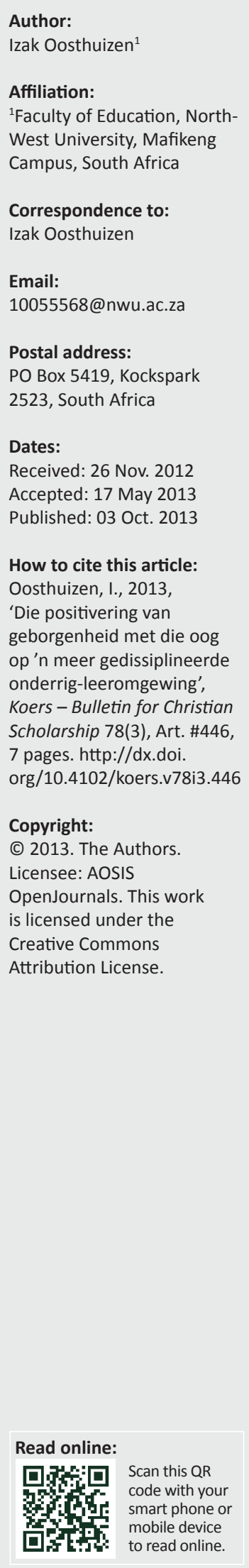

Leerderwangedrag het 'n groot probleem in Suid-Afrikaanse skole geword en dit skyn die gesonde onderrig-leeromgewing te belemmer. Die metode wat in hierdie beredenerendbesinnende artikel gebruik word, is 'n dekonstruksie van konstrukte soos geborgenheid en burgskap met die oog daarop om aan te toon hoe die korrekte benadering daartoe en die uitvloeisels daarvan in die onderrig-leeromgewing geaktualiseer kan (en behoort te) word. Uit die ondersoek blyk dat geborgenheid, wat basies veiligheid en beskerming impliseer, sinvol in die onderrig-leeromgewing geaktualiseer behoort te word deur die aktivering van 'n toepaslike geborgenheidsburgskap. Ten einde sodanige aktivering op 'n verbeterde vorm van geordende onderrig en leer te rig, behoort daar op die ontwikkeling van toepaslike geborgenheidsruimtes vir die bevordering van dissipline en orde in die klaskamer gefokus te word.

Enhancing discipline in the learning and teaching environment by means of geborgenheit. Learner misconduct is a grave concern in South African education due to the negative effect it is having on teaching and learning. The approach in this argumentative and reflective article is one of deconstruction of constructs such as geborgenheit [secureness] and stronghold. The objective is to demonstrate how these concepts can be actualised to enhance a sound and orderly learning and teaching environment. An analysis shows that geborgenheit, which essentially entails protection and fostering, needs to be linked to, and actualised in the particular teaching and learning environment by activating an applicable geborgenheit-stronghold. For successful actualisation of the latter, it is crucial to unlock the applicable geborgenheit spaces for the enhancement of orderly teaching and learning in the classroom.

\section{Inleiding}

Suid-Afrikaanse media fokus die afgelope dekade dikwels op een of ander onrusbarende aangeleentheid in die onderwys. Soms kom die algemene gedrag van die onderwyser in die kollig, terwyl 'n meer sensitiewe aangeleentheid soos die seksuele omgang van skooldogters tydens skoolure (met gepaardgaande swangerskappe) by 'n ander geleentheid weer onder die loep geneem word (Snyman 2012:466). So 'n mediaberig oor die onderwys skep uiteraard die indruk dat alles nie pluis is in die Suid-Afrikaanse onderwys nie (Snyman 2011:421). 'n Dekade gelede het skrywers reeds aangetoon dat leerderwangedrag besig is om in 'n akute probleem in Suid-Afrikaanse skole te ontaard (Wolhuter \& Steyn 2003:521). Gedurende dieselfde periode waarsku regslui dat die inwerkingtreding van die Suid-Afrikaanse Grondwet besig is om 'n verandering in die hantering van leerderwangedrag teweeg te bring waarby onderwysers sal moet aanpas (Roos 2003:499).

Die besef dat die onderwys met baie probleme opgesaal sit, word bevestig wanneer onlangse navorsingsverslae oor die onderwys ontleed word (Holborn 2013:1). Trouens, baie van die verslae skep die indruk dat die gehalte van die onderwys besig is om agteruit te gaan. Een van die kritiese aspekte wat deesdae in die onderwysdialoog opgeneem word, is die verswakking van leerlinge se onderrig- en leeruitkomste (Snyman 2013:2). In die huidige tydsgewrig wil dit voorkom asof leerderwangedrag tot so 'n mate toegeneem het dat dit dikwels as een van die belangrikste redes vir die agteruitgang van onderwys in Suid-Afrika uitgewys word. Navorsing wat deur die Federasie vir Beheerliggame van Suid-Afrikaanse Skole onderneem is, het byvoorbeeld aangetoon dat die ongedissiplineerde gedrag van leerlinge die enkele grootste faktor is wat die gehalte van onderrig en leer aftakel (Rademeyer 2011:12).

\section{Probleemstelling}

Literatuur oor leerderwangedrag toon dat daar veral vyf faktore is wat 'n invloed op leerderwangedrag uitoefen, naamlik samelewingsfaktore, die invloed van leerlinge, ouers, 
onderwysers en die skole (Wolhuter, Oosthuizen \& Van Staden 2010:170). Aangesien hierdie besinning hoofsaaklik op die onderrig-leeromgewing gemik is, word daar verderaan slegs op die onderwysers, skole en leerders gefokus.

Voorvalle van leerderwangedrag hou dikwels psigiese leed in vir medeleerlinge. Gevalle van leerderwangedrag waarvan daar in die media melding gemaak is, het onder andere aangetoon dat die voorkoms van bullebakkery onder leerlinge in Gautengse skole gedurende 2012 sulke afmetings aangeneem het, dat sewe leerlinge by een geleentheid by ' $n$ bepaalde skool geskors moes word. Die negatiewe gevolge wat afknouery vir die slagoffers ingehou het, sluit voorvalle van selfmoord, slaapversteurings, angs en skoolverlating in (Rademeyer 2012a:8). In 'n ander geval kry die 11-jarige slagoffer van afknouery byvoorbeeld gereeld angsaanvalle en ly hy aan slaapversteurings. Trouens, hy is tot so 'n mate daardeur getraumatiseer dat hy vir die grootse gedeelte van 2011 nie verder kon skoolgaan nie (Wondergem 2011:10).

Sekere vorms van ernstige leerlingwangedrag hou dikwels 'n daadwerklike bedreiging vir die fisiese welsyn van leerlinge in. Mediaberigte toon aan dat'n hoërskoolleerling gedurende polisie-klopjagte by sy skool in hegtenis geneem is vir die besit van kokaïne ter waarde van R17 500. In nog 'n geval is 11 leerlinge tydens 'n klopjag by 'n skool in Pretoria positief getoets vir die gebruik van dagga (Fourie 2011:8). 'n Dogter van 14 jaar is verkrag nadat sy deur 'n medeleerling by die skool opgelaai is en in ' $n$ ander geval is 'n graad 7-leerling deur 'n groep van drie jeugdiges verkrag (Pretorius 2011:5; Brits 2010:15). 'n Hoërskooldogter het springstoftoestelle skool toe gebring wat sy aan ' $n$ medeleerling gegee het om te aktiveer. Toe laasgenoemde dit tydens skoolure geaktiveer en laat ontplof het, het ' $n$ ander leerling ernstige beserings opgedoen (Versluis 2011:4). 'n Graad-10 leerling is by die skool deur 'n medeleerling met 'n skêr in die bors gesteek en in ' $n$ ander geval is ' $n$ 15-jarige by die skool doodgesteek na 'n geveg oor 'n selfoon (Louw-Carstens 2012:2; South African Press Association 2012:4).

Ingevolge hulle professionele kode is onderwysers as professioneel opgeleide kundiges tot die skep van 'n geborgenheidsklimaat in die klas- en die skoolomgewing verbind ten einde 'n effektiewe onderrig-leerverloop te verseker. Die vertrouensverhouding tussen onderwysers en leerlinge is in hierdie konteks van deurslaggewende belang. Hierdie verhouding word egter dikwels geskaad deur 'n gebrek aan kundigheid. In die saak waar 'n laerskoolhoof op 'n klagte van aanranding op 'n leerling teregstaan, is daar min blyke van so 'n vertrouensverhouding (Rademeyer 2012b:1).

Die voorafgaande oorsig beskryf 'n toestand van ongeborgenheid vir die betrokke leerlinge. Dit is pedagogies verontrustend, aangesien geborgenheid van die leerling, as 'n sine qua non ['n noodsaaklike toestand of element] vir goeie onderwys bestempel word (Oosthuizen 2011:1). In gevalle soos bogenoemde is dit duidelik dat daar nie sprake van 'n aanvaarbare geborgenheidsruimte in die klaskamer en/of op die skoolperseel is nie.

\section{Die metode van ondersoek}

Literatuursoektogte na inhoude in die opvoedkunde wat oor die begrip geborgenheid handel, het getoon dat daar oor die afgelope vier dekades nie veel meer daaroor geskryf is as om dit semanties te ontleed en/of om enkele gepaardgaande toepassingsvoorbeelde daarvan te gee nie (Van der Walt \& Dekker 1983; Vaughan 1975; Van Zyl 1975; Oosthuizen 2011). Geen omvattende teoreties-filosofiese onderbou of konstruk van die begrip met betrekking tot die Opvoedkunde kon opgespoor word nie. In die lig hiervan is dit belangrik om die geborgenheidsbetekenisomgewing te ontgin ten einde dit tot ' $n$ toepaslike teoreties-filosofiese onderbou in die Opvoedkunde te kan uitbou.

Hierdie artikel is kontensieus van aard, met die implikasie dat daar reflektief-beredenerend te werk gegaan word met die doel om teëspraak en/of gespreksvoering te stimuleer. Hierdie gespreksvoering kan uiteindelik bydra tot die verbreding van 'n filosofies-teoretiese raamwerk vir geborgenheid en om die toepaslikheid daarvan binne die opvoedende-onderwysomgewing aan te toon.

In hierdie proses moet die wesensaard van geborgenheid verder ontleed word, daar moet 'n essensiële geborgenheidsburg geïdentifiseer word en dit moet aangetoon word hoe om sodanige burgte as geborgenheidsontsluitingsruimtes te beskou. In die laaste instansie het hierdie artikel ook ten doel om die teoreties-filosofiese raamwerk te kan toepas op die handhawing van groter orde en dissipline in die onderwyspraktyk.

Hierdie artikel word vanuit 'n Christelike lewensbeskoulike perspektief geskryf. Orde is nie net een van die grondbegrippe in die onderwys nie - dit is veel meer. Orde is ook een van die essensiële kenmerke van die Christelike lewenswandel. Die Griekse woord vir orde, taxis, word gebruik wanneer Paulus die gemeente van Kolosse in Kolossense 2:5 aanprys oor hulle (orderlike) gedissiplineerde Christelike lewenswandel (Renn 2005:204). In 1 Korintiërs 14:40 word die woord taxis weer gebruik wanneer Paulus die gemeente vermaan om toe te sien dat hulle eredienste nie wanordelik verloop nie, maar dat dit 'gepas en ordelik moet geskied'. Dake (2007:526) voer aan dat geen groep as 'n kerklike gemeente kan funksioneer sonder die aanwesigheid van orde en reëlmaat nie. Hy wys voorts daarop dat enigiets wat die Here skep of verordineer, deur wet en orde gereguleer word en dat onordelike wetteloosheid nie uit God is nie.

Ten einde die voorafgaande te bewerkstellig, word interpretivisties-konstruktivisties en konstruktivistiesrealisties te werk gegaan. Alvorens die beoogde konstruk in 'n heuristiek omskep kan word, word daar eers van 'n dekonstruktiewe benadering (Cupchick 2001:13) gebruik gemaak. Hiervolgens is elkeen van die sleutelbegrippe soos geborgenheid, burgskap en geborgenheidsruimte gesegmenteer 
en aan 'n selektiewe fokus van begripsontleding onderwerp. Die resultaat van hierdie realisties-interpreterende en realisties-konstruktiverende poging is dat 'n heuristiek gevorm kon word waarmee 'n bydrae gemaak kan word tot die handhawing van groter orde en dissipline in die onderwyspraktyk. Die term heuristiek is afgelei van 'n Griekse woord wat beteken om te ontdek of om te onbloot en dit verwys gewoonlik ook na die instrument(e) waarmee 'n probleem benader, verklaar en hopelik opgelos kan word (Mouton 2007:14). 'n Heuristiese model is voorts op die stimulering van gedagtes, argumente en teenargumente vir en teen bepaalde standpunte of verskynsels gerig. Heuristiese modelle in die sosiale wetenskappe word nie as waar of vals bestempel nie, maar eerder as bruikbaar of minder bruikbaar (Linde 2003:37). In die onderhawige artikel word gebruik gemaak van 'n denkkonstruk (vgl. Figuur 1) as heuristiek (verklaringsmodel) om die rol en funksionering van geborgenheid in die alledaagse onderwyspraktyk uit te beeld.

Om te toon hoe geborgenheid as heuristiek aangewend kan word, is die res van hierdie artikel soos volg gestruktureer. Eerstens word die konseptueel-teoretiese raamwerk aangebied waarin die ondersoek ingebed is. Daarna volg'n uiteensetting van die bevindings na die toepassing van die heuristiek, waarna die artikel met enkele aanbevelings afgesluit word.

\section{Die teoreties-konseptuele raamwerk Geborgenheid}

In Afrikaans beteken die woord geborgenheid letterlik die 'toestand om geborge te wees', "n toestand van veiligheid en vryheid van bekommernis en sorg' (Schoonees et al. 1972:54). Semanties hou die woord geborgenheid ook verband met die woorde bêre en wegsit (Boshoff \& Nienaber 1967:160). Die Afrikaanse betekenis van die woord bêre is 'in veiligheid bring, red, wegsit, op 'n bestemde plek plaas, spaar, weglê en opberg' (Schoonees et al. 1972:374). Die semantiese koppeling met die woord bêre toon vervolgens aan dat dit verwant is aan die Nederlandse en Hoogduitse woord bergen wat op sy beurt weer sy oorsprong in die Oudslawiese woord brega het, wat letterlik beteken om te sorg vir (Boshoff \& Nienaber 1967:160). In moderne Nederlands word die verlede deelwoord van bergen as geborgen aangetoon (Geerts \& Heestermans

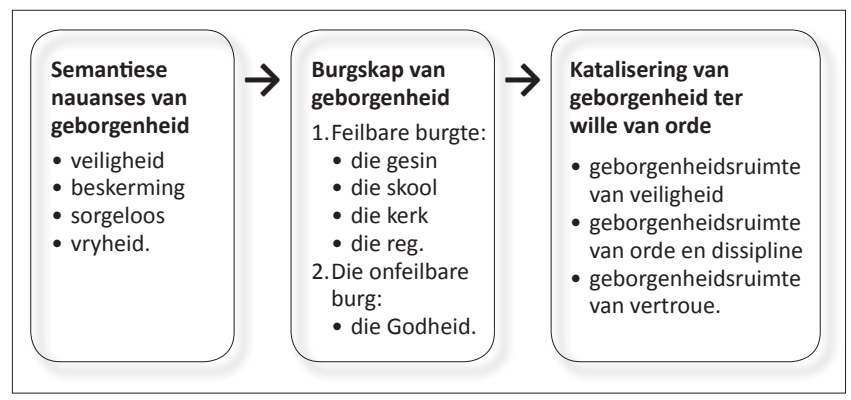

FIGUUR 1: Die positivering van 'n geborgenheidsburgskap in 'n geordende skoolomgewing.
1992:110). Daarbenewens is bêre ook etimologies verwant aan Nederlandse woorde soos burcht, burg, borg, hergberg woorde wat almal in die ondertoon van die begrip veiligheid ondervang word (Boshoff \& Nienaber 1967:160). In die Nuwe Vertaling van die Nederlandse Bybelgenootskap word die woord bergen algemeen as aanduiding gebruik van die veilige skuiling wat God bied.

Dit is betekenisvol om die Bybelse kontekstualisering van bergen na te speur:

- In die aanvegtings van die listige tong beskerm Hy (Job 5:21; Ps 31:21). In laasgenoemde geval word die Afrikaanse woord hut as plek van beskerming aangetoon. Op ander plekke in die Psalms (Ps 27:5; 31:21) versteek God die vlugteling in sy en haar hut om hom en haar teen die onheil te beskerm. In die lig van die Hebreeuse poësie moet die sintetiese alternatief in die verse ook in ag geneem word en kan die skuilplek ook God se tent (Ps 27:5; 61:5) of sy aangesig wees (Ps 31:21).

- God as burg word telkens ook as God se vleuels verbeeld (Ps 17:8; 61:5): wanneer die goddelose vyand met geweld op die gelowige toesak, is die skadu van God se vleuels die plek van beskutting. Die skuilplek onder God se vleuels word op die ark se versoendeksel uitgebeeld (vgl. die beskrywing in Heb 9:5). Twee engele (gerubs) sprei hulle vlerke na mekaar en vorm 'n skadu, 'n beskutting op die deksel. Hierdie skadu is genoem die plek van versoening. Hiervolgens is die diepste sin van veiligheid onder God se vleuels waar God se vergifnis te vind is. Die diepste vrede, veiligheid en geborgenheid is in versoening met God.

- Sion, dit wil sê Jerusalem en die tempel, is die plek waar Israel hulle skuiling moet gaan neem (Jer 4:6) teen die magtige nasie uit die Noorde. Indien die getroues na God soek en na geregtigheid en ootmoedigheid sal hulle dalk 'geborgen worden', dit wil sê veilig wees die dag as die vyand Jerusalem binneval (Nel 2012:1).

Enkele Hebreeuse woorde wat in die Nuwe Nederlandse Vertaling met bergen vertaal word, is die volgende:

- In Psalm 17:8, 27:5 en 31:21 word die woord gebruik - dit kan ook beteken toemaak, heelmaak of versteek.

- In Job 5:21 word die woord חבא [kha-ba] gebruik wat in die verbuigingsvorms daarvan begrippe soos wegsteek en koester met liefde insluit.

- Die Hebreeuse woord [kha-sa] wat in Psalm 61:5 gebruik word, beteken onder andere om na veiligheid te vlug, te gaan skuil of om vertroue in iets te hê. Dit is ook die mees algemene woord vir veilige skuiling en kom 37 keer in die Ou Testament voor. Figuurlik gesproke beteken dit om te vertrou in of veilig te voel by. Met twee uitsonderings (Rig 9:15; Ps. 25:20) word die werkwoord vertaal met 'n daad van vertroue in God (Strong 1995:39, 46, 101).

Samevattend kan gesê word dat die begrip geborgenheid breed strek en 'n verskeidenheid nuanses van veiligheid en sekuriteit behels. 'n Ontleding toon aan dat die woord 
'n veelheid aanverwante nuanses soos byvoorbeeld veiligheid, beskerming, beskutting, berging en bedekking omvat. Vervolgens kan hierdie woord ook in 'n hele aantal toepassingsvlakke gebruik word. Voorbeelde hiervan sluit onder andere die volgende in: die toepassingsvlak van lokaliteit wat plekke van geborgenheid aantoon; die toepassingsvlak van gesteldheid wat die toestand of staat van 'n persoon aantoon; die toepassingsvlak van belewenis wat die innerlike menslike belewenis of ervaring van geborgenheid aantoon; die toepassingsnuanse van verwagting wat die ondertoon van die menslike nood (behoefte) aan 'n staat van ewigdurende vrede en veiligheid verbeeld.

\section{Burgskap van geborgenheid}

Soos uit die voorafgaande blyk, bestaan daar 'n noue verband tussen die begrip geborgenheid en die begrip burg. Burg, wat toevlugsoord beteken, kan gevolglik as't ware gesien word as 'n plek van veiligheid (geborgenheid). Die ouerhuis en die regstelsel is onder andere voorbeelde van sodanige burgte, omdat dit op grond van hulle sinkern 'n gerigtheid tot beskerming vertoon. Die gesin is op die beskerming van die kind gerig, terwyl die reg ingestel is op die beskerming van wedersydse regte, verpligtings en kompetensies (Van der Walt \& Dekker 1983:254; Hosten 1995:293). In hierdie artikel word ' $n$ versameling van ' $n$ aantal burgte 'n burgskap genoem. Nie net dien so 'n burgskap as 'n versamelplek van veilige plekke nie, maar dit stel ook veiligheid vry. Anders gestel, die burgskap dien as 'n katalisator vir die vrystelling van geborgenheid. Die burgte wat deel uitmaak van die besondere burgskap wat hieronder bespreek gaan word, is die volgende: die hoogste Burg is die Godheid. Dit is die enigste Burg wat onfeilbaar is. Weens die menslike feilbaarheid en gebrokenheid is al die ander burgte aan feilbaarheid onderworpe.

Die diepste sin van veiligheid, vrede en sekuriteit is die mens se innerlike versugting na Goddelike geborgenheid (Nel 2012:1). Die universele menslike behoefte aan geborgenheid is waarskynlik in die mens se verlange na die beskerming van die ewige Burg gesetel; mense vind die grondslag van hulle individuele geloof in God wat inderwaarheid die enigste plek is waar die mensheid geborgenheid volledig kan beleef. Hierdie nood aan veiligheid vind uitdrukking in 'n soeke na die Here se beskermende liefde wat red, vergewe en die swakkeling versterk:

The love of God is protecting love, is above that which makes the wonderer wise, the weak strong, the sinner pure, the captive of $\sin$ the free man of holiness. [Die beskermende liefde van die Here verhef die twyfelaar tot ' $n$ wyse; dit maak die swakkeling sterk, suiwer die sondaar en verander die gevangene tot ' $n$ bevryde heilige.] (Barcley 1958:186, [outeur se eie vertaling])

God is as Burg vir gelowiges die rots (Deut 32:37), die skild (Ps 144:2; Spr 30:5) en selfs die hen met uitgestrekte vlerke (Ps $57: 1 ; 61: 4)$ waarby hulle gaan skuil.

Die burg van die ouerhuis of die gesin dien as die primêre samelewingskring wat op die geborgenheidspostivering in die lewe van die kind gerig is. Daar is geen ander samelewingskring wat mense so intiem saambring as juis die konvensionele gesin nie. Die gesin is ' $n$ konstante liefdesgemeenskap wat die weerspieëling is van die Godheid en die Christengemeenskap (Schoeman 1978:116). Die rede vir hierdie intimiteit is ingebed in die ondertone van bloedbande, huweliksbande en bande van onderlinge verantwoordelikhede wat die gesinslede saambind (Van der Walt \& Dekker 1983:254). Die kern van die opvoedingsbemoeienis met die kind word in die ouerhuis gelê om die kind na 'n staat van volwasse wasdom te begelei.

Die skool dien ook as 'n burg van geborgenheid vir die leerling. Een van die wesenskenmerke van ware opvoeding is 'n geborgenheidsbelewenis deur die kind en 'n gevoel van veiligheid wat deur die onderwyser se toedoen opgewek word (Van der Walt \& Dekker 1983:198).

Die reg as burg van geborgenheid vertoon 'n verskeidenheid regsdeterminante wat die geborgenheid van die kind beskerm. Een van die mees dinamiese statutêre instrumente wat die geborgenheid van die kind beklemtoon, is waarskynlik die grondwetlike imperatief van artikel 28(2) wat die beste belange van die kind voorop stel. Hierdie artikel bepaal naamlik dat die beste belange van die kind in alle aangeleenthede wat die kind raak, telkens as die deurslaggewende oorweging moet dien (Suid-Afrika 1996a). Laasgenoemde bepaling is ' $n$ bevestiging van artikel 3 van die Internasionale Konvensie van die Kind van 1990 waarin daar bepaal word dat in alle aksies rakende die kind, die kind se beste belange die hoofoorweging sal geniet - hetsy aksies wat geloods word deur openbare of private welsynsorganisasies, howe of administratiewe liggame (Verenigde Nasies [VN] 1990).

\section{Die ontsluiting van geborgenheidsruimtes vir gedissiplineerde onderrig-leer}

In hierdie afdeling word eerstens op die leerling se nood aan geborgenheid in die onderrig-leeromgewing gefokus. Daarna word aangetoon hoe 'n katalisering van geborgenheid vanuit die geborgenheidsburgskap benut kan word om 'n geordende onderrig-leeromgewing vir die leerling te verskaf.

Die stelling word dikwels gemaak dat geborgenheid in sy veelheid van aanverwante betekenisonderskeidings 'n pilaar is waarop sinvolle opvoedende leer gebou moet word (Oosthuizen 2011:1). Insgelyks word dit ook as 'n fundamentele voorwaarde vir die suksesvolle opvoeding en ontwikkeling van die kind beskryf (Vaughan 1975:1).

Uit die aard van hulle onvolwassenheid bevind veral kinders hulself in 'n staat van afhanklikheid (Barcley 1958:176). Inderwaarheid is die kind as hulpbehoewende aangewese op geborgenheid om te kan oorleef. Reeds vanaf geboorte, met die knip van die naelstring, verkeer die kind onder andere in 'n geborgenheidsnood om asemhaling, voeding en fisiese versorging (Oosthuizen 2011:1). Hierdie nood aan geborgenheid word deur 'n verskeidenheid burgte - wat as't ware as toevlugsoorde dien - ondervang. 
Die positivering van die geborgenheid wat vanuit die geborgenheidsburgskap vrygestel word, maak dit vir die leerling moontlik om in die verskillende fasette van sy en haar menswees tot volwassenheid te gedy. Die kind is kunstig saamgeweef in 'n holistiese geskapenheid van siel, liggaam en gees wat 'n veelheid van fasette behels. Elkeen daarvan is aangewese op die ontsluiting van byvoorbeeld die verstandelike, sedelik-morele, sosiale, estetiese, liggaamlike en religieuse (Van Loggerenberg \& Jooste 1980:45-88).

Gedurende die skolingsjare ervaar kinders as onvolwassenes ' $n$ nood aan die geborgenheid van vakkundige kennis, emosionele volwassenheid sowel as lewens- en beroepsvaardighede. Die kinders moet gevolglik as leerlinge toegerus word deur in die klaskamer aan 'n onderrig-leeromgewing blootgestel te word waarin hulle die nodige vaardighede en kennis kan verwerf.

Ten einde optimale onderrig en leer te bevorder, moet daar 'n aktivering van 'n verskeidenheid geborgenheidsruimtes plaasvind. Enkele voorbeelde van essensiële geborgenheidsruimtes vir geordende onderrig en leer word vervolgens bespreek.

\section{'n Geborgenheidsruimte van dissipline}

Die woord dissipline is afkomstig van die Latynse woord discere wat onder andere beteken 'om te leer' (Postma 1985:93). Dissipline in sy enger betekenis dui op orde en die handhawing van orde ten einde hindernisse te voorkom en die steuringsvrye verloop doelmatig te bevorder (Landman et al. 1978:346). Doelgerigtheid en die verwydering van hindernisse op die pad na die einddoel word in die brief aan die Hebreërs as een van die essensies van die Christenlewe uitgebeeld (Barcley 1957:171).

As gevolg van die feit dat onderwys nie in 'n lugleegte, losstaande van die regsomgewing funksioneer nie, is orde 'n noodwendige voorvereiste vir onderrig en leer (Prinsloo \& Beckman 1989:48). In die skool waar die skoolbestuur aangewese is op 'n groot verskeidenheid maatreëls ten einde 'n geordende verloop van aktiwiteite te verseker, word orde in den brede beskou as die ontiese vertrekpunt vir die regulering van alle tersaaklike aktiwiteite wat essensieel is vir 'n sinvolle onderwysverloop (Van der Westhuizen 1990:12).

Artikel 8 van die Suid-Afrikaanse Skolewet en die gepaardgaande Riglyne vir die Oorweging deur Beheerliggame vir die Aanvaarding van ' $n$ Gedragskode vir Leerlinge is uitdruklik op die daarstelling van orde gemik ten behoewe van die leerverloop.

Volgens die voorgemelde bepalings van die Suid-Afrikaanse Skolewet het die daarstelling van 'n gedragskode vir leerlinge veral ten doel om die instandhouding van'n gedissiplineerde (en ordelike) leeromgewing (van geborgenheid) te bevorder wat doelgerig fokus op die onderhouding en verbetering van gehalte leer (Suid-Afrika 1996b).

Item 1 van voorgemelde Riglyne stel dit duidelik dat Beheerliggame by die opstel van 'n skool se gedragskode die gedissiplineerde verloop van die leerproses by die skool voor oë moet hou. Dit beveel ook aan dat die skool se benadering tot ongedissiplineerde leerlinge eerder deur positiewe gerigtheid gekenmerk moet word as deur 'n strafgerigte ingesteldheid (Suid-Afrika 1998).

\section{Fisiese geborgenheidsruimte}

Die fisieke onvolledigheid van kindwees gedurende die opgroeiende ontwikkelingsfase beteken dat die kind fisiek kwesbaar is en aangewese is op 'n geborgenheid van fisieke beskerming. Die opdrag aan die ouers om na die fisieke beveiliging van die kinders om te sien, word op verskillende plekke bevestig:

Artikel 28 van die Suid-Afrikaanse Grondwet (Suid-Afrika 1996a) dring aan op die voorsiening van genoegsame voeding, beskutte huisvesting, basiese gesondheid en maatskaplike sorg van die kind.

By die skool bevind die onderwysers hulle in die plek van die ouers en vervul gevolglik in hierdie verband die sogenaamde in loco parentis-rol [in die plek van 'n ouer] as die sekondêre opvoeders. Een van die regsvereistes wat aan die in loco parentis-persoon gekoppel word, behels die sorgsame toesighoudingsplig oor die leerling. Toesig in hierdie konteks impliseer die funksie van sorgsame bewaking of versorging van die minderjarige leerling. Dit impliseer gevolglik die verskaffing van 'n geborgenheidsruimte ten behoewe van die fisieke en geestelike beskerming van die leerling. Enkele van die Suid-Afrikaanse hofsake wat die gedagte van fisieke veiligheid beklemtoon, is onder andere Rusere v Jesuit Fathers (1970), Broom en andere v Die Administrateur van Natal (1966), Knouwds v Administrateur van die Kaap (1981) en Minister of Education and Culture $v$ Azel and another (1995).

\section{'n Geborgenheidsruimte van vertroue}

Covey maak die stelling dat vertroue die een ding is wat alles verander en dat dit'n essensiële determinant is vir die verloop en uitkoms van alle aspekte van menslike wedersydse en wisselwerkende onderlinge verkeer (Covey 2006: inleidende opmerking). Die opvoedingsomgewing is ook afhanklik van die wedersydse vertroue tussen veral die leerling en die onderwysers. Vertroue dien as 'n geborgenheidsruimte vir sinvolle onderrig en leer. Dit is trouens ' $n$ onontbeerlike voorvereiste vir enige sinvolle opvoeding (Van Zyl 1975:245).

Een van die grondslae vir enige vertrouensruimte is geloofwaardigheid. Die vier pilare vir geloofwaardigheid (toegepas op die onderrig-leeromgewing) is die volgende:

- Die integriteit van die onderwyser, wat eerlikheid en deursigtigheid impliseer.

- 'n Opregte ingesteldheid van dienslewering deur die onderwyser, wat gerig is op die verwesenliking van die gesamentlike doel, naamlik die opvoeding van die leerling; dit impliseer dus die afwesigheid van 'n gerigtheid tot eiebelang en verskuilde motiewe.

- Die vermoëns van die onderwyser in die vorm van talente, vaardighede, (vak)kundigheid en vakkennis. 
The Teaching and Learning International Survey (TALIS) se ondersoek na die effektiewe hantering van leerderdissipline het 'n positiewe verband tussen die professionele ontwikkeling van die onderwyser en die hantering van leerderdissipline aangetoon; dit het geblyk dat hoe hoër die vlak van die onderwysers se professionele ontwikkeling, hoe positiewer was die vlak van leerdergedrag (Organisation for Economic Cooperation and Development 2009:119, 133).

- Die bevoegdheid van onderwysers soos dit gereflekteer word in die uitkomste wat blyk uit die onderwysers se bewese rekord van hulle leerlinge se uitslae; in 'n ondersoek na die effektiewe metodes vir die hantering van wangedrag in die Kenneth Kaunda-distrik van die Noordwesprovinsie van Suid-Afrika is bevind dat die mees effektiewe metodes om leerlinge se wangedrag te beheer, inderdaad te make het met die onderwyser se bevoegdheid. Uit 'n rangorde van 22 opsies vir die hantering van wangedrag wat in die ondersoek gelys is, is die bevoegdheid van die onderwysers as vakkundiges sowel as hulle vlak van voorbereiding uitgewys as die twee mees effektiewe metodes (Oosthuizen 2007:14). (vgl. Covey 2006:54)

\section{Sintese}

Geborgenheid word as 'n sine qua non vir doeltreffende onderwys bestempel. Die Suid-Afrikaanse onderwys bevind hom egter in vele opsigte in 'n staat van ongeborgenheidsbelewing en het gevolglik ' $n$ behoefte aan die implementering van geborgenheid op verskeie terreine van die onderwyspraktyk. Die positivering van geborgenheid in die onderwyspraktyk, meer spesifiek die onderrigleeromgewing, is in die voorafgaande gedeeltes met behulp van 'n teoretiese verklaringsmodel (vgl. Figuur 1 ) voorgestel ten einde te probeer aantoon hoe geborgenheid in ' $n$ tipiese onderrig-leeromgewing gepositiveer kan word. Dit blyk dat hierdie konstruk tot 'n groot mate werklikheidsgetrou is en dat die voorstelling van geborgenheidsaktualisering in die onderskeie pedagogiese fasette (geborgenheidsruimtes) van die onderrig-leerpraktyk oortuigend uitgebeeld kan word. Die rede vir hierdie gevolgtrekking word stap vir stap aan die hand van die konstruk (vgl. Figuur 1) bespreek. Die konstruk se drie hoofmomente bestaan uit 'n semantiese verheldering van die begrip geborgenheid; die uiteensetting van vier burgte (die ouerhuis, die skool, die reg en die Godheid); en enkele geborgenheidsruimtes van die onderrig-leeromgewing waarin geborgenheid gebied word. Elkeen van die drie hoofmomente en die wisselwerkende interaksie daarvan word aan die eis vir werklikheidsgetrouheid gemeet.

Die betekenisnuanses van die woord geborgenheid is as't ware getrianguleer deur dit aan die semantiese verbande van Afrikaans, Hoogduits, Hollands en Hebreeus bloot te lê.

Daarbenewens is die konsep van geborgenheid ook vanuit verskillende tydsgewrigte beskou in die lig van die etimologiese skakels wat dit met die Ou-Testamentiese sowel as die moderne wêreld deel. Die ooreenstemmende betekenisuitleg is ook in ' $n$ verskeidenheid bronne, wat op verskillende plekke en tye deur verskillende persone opgeteken is, bevestig. Die ryke betekenis van die woord geborgenheid is dienooreenkomstig in die verklaringsmodel aangetoon.

Die semantiese nuanses van die woord geborgenheid is op sigself nie veel meer as 'n abstraksie nie. Die konsep geborgenheid moet in verband gebring word met ander konsepte om geaktualiseer te word. Soos dit aan die begin van hierdie artikel aangetoon is, is 'n konsep wat in 'n semantiese verwantskap met die konsep geborgenheid staan, te vind in die woord burg (meervoud: burgte). Soos in die bespreking pas aangetoon is, dui die burg-konsep 'n plek van beskerming en/of beskutting aan - dus 'n toevlugsoord; dit dra dus in hierdie opsig 'n lokaliserende konnotasie. Andersyds blyk dit ook dat dit 'n plek is waar die krag van beskerming vrygestel en getransponeer kan word na diegene wat 'n nood aan beskerming, oftewel geborgenheid het. Dit dien dus as ' $t$ ware as ' $n$ aktualisering wat geborgenheid vrystel om in die lewende praktyk (onderwyspraktyk) gepositiveer te word. Daar bestaan uiteraard vele vorms van burgte. Die burgskap wat in die bespreking van die konstruk (vgl. Figuur 1) gebruik is, dien as voorbeelde om die operasionalisering van die konstruk te demonstreer. Die wederkerige en interafhanklike funksionering van die onderskeie burgte binne die burgskap blyk onder andere duidelik in die geval van die ouerhuis, die skool en die reg. Die burgte van die ouerhuis en die skool word deur die burg van die reg bevestig en versterk. Die enigste Burg wat algenoegsaam is en geen bevestiging of versterking nodig het nie, is die Goddelike Burg wat op sigself 'die weg en die waarheid' is.

Die positiveringsproses van geborgenheid in die lewenspraktyk is hierbo gedemonstreer deur enkele voorbeelde uit die onderrig-leerpraktykfasette (vgl. Figuur 1). Hierdie praktykvoorbeelde is telkens aan die praktykegtheid van die onderwyspraktyk getoets deur die essensies van elkeen te toets uit ' $n$ verskeidenheid bronne, insluitende navorsingsverslae wat eweknie-keuring deurstaan het.

'n Onderrig-leeromgewing is saamgestel uit 'n vervlegtheid van aspekte en faktore of submomente wat die wesensaard en gang van elke besondere onderrig-leeromgewing stuur. Hierdie aspekte is onnoembaar baie in omvang en sluit onder andere die volgende in: verhoudingspatrone tussen leerlinge en onderwyser(s), interpersoonlike verhoudings tussen die leerlinge, die leerlinge se geslag, ouderdomme en volwassenheidsvlakke, die aard van die besondere vak wat aangebied word, die vaardighede en kundigheid van die onderwyser, die onderwyser se persoonlikheid, karakter, norme, emosionele intelligensie, en vele meer. Die feit bly staan dat elkeen van die deelnemers hieraan 'n nood aan geborgenheid het wat geaktiveer moet word ter bevordering van geoptimaliseerde onderrig en leer. Slegs enkele geborgenheidsruimtes wat in die konstruk veronderstel word, is bespreek om die aktivering van geborgenheid te demonstreer. 
Die heuristiek wat in hierdie artikel gebruik is, toon egter ook sekere tekortkomings. Die eerste is dat daar net op een faset van die onderwys gefokus is, naamlik die onderrigleeromgewing. Die omvang van die onderwys in geheel is egter te ' $n$ groot opgaaf om in hierdie beginstadium van teorie-ontwikkeling te poneer.

Tweedens behoort meer burgte en burgskappe as die vyf wat in die burgskapskonstruk vroeër in die artikel gebruik is, geïdentifiseer te word. Slegs vier voor die hand liggende burgte is bespreek. Hierdie poging moet gevolglik net as 'n eerste tree op die pad na die identifisering van die volle opgaaf van burgte vir die onderwys gesien word.

In die derde plek moet vermeld word dat daar'n groot opgaaf van fasette is wat in die onderrig-leeromgewing ingeweef is. Slegs drie van hierdie fasette is in die geborgenheidsruimtes van die konstruk bevestig en getoets. Veel meer van hierdie fasette behoort nog getoets te word.

\section{Slotsom}

Geborgenheid is ' $\mathrm{n}$ sine qua non vir geordende onderrig en leer. Die volgende kan dus gestel word: Gelukkig is die leermeesters wat self geborgenheid in hulle ronddra en dit ook kan uitgiet oor hulle geborgenheidsbehoewende leerlinge.

\section{Erkenning \\ Mededingende belange}

Die outeur verklaar dat hy geen finansiële of persoonlike verbintenis het met enige party wat hom nadelig of voordelig kon beïnvloed het in die skryf van hierdie artikel nie.

\section{Literatuurverwysings}

Barcley, W., 1957, The letter to the Hebrews, Westminster John Knox, Louisville. Barcley, W., 1958, The Gospel of Matthew, vol. 2, Westminster John Knox, Louisville. Boshoff, S.P.E. \& Nienaber, G.S., 1967, Afrikaanse etimologieë, Suid-Afrikaanse Akademie vir Wetenskap en Kuns, Pretoria.

Brits, J., 2010, '18-jarige net 5 jaar tronk toe', Beeld, 15 Desember, bl. 15.

Dake, F.J., 2007, God's plan for man, Dake Publishing, Lawrenceville.

Covey, S.M.R., 2006, The speed of trust, Simon \& Schuster, New York.

Cupchick, G., 2001, 'Constructivist realism: An ontlogy that encompasses positivist and constructivist approaches to the social sciences: Forum [Konstruktivistiese realisme: 'n Ontologie wat positivistiese en konstruktivistiese benaderings tot die sosiale wetenskappe omvat: Forum]', Qualitative Social Research 2(1), 1-28

Fourie, H., 2011, ' 11 by skool positief getoets vir dagga', Beeld, 06 Augustus, bl. 8.

Geerts, G. \& Heestermans, H., 1992, s.v. 'bergen', Van Dale groot woordenboek der Nederlandse taal, Van Dale, Utrecht, bl. 110.

Holborn, J., 2013, Time to take the shine off the school story: Fast facts, South African Institute of Race Relations (SAIRR), Johannesburg.

Hosten, W.J., 1995, Introduction to South African law and legal theory, Butterworth, Durban.

Landman, W.A., Roos, S.G., Barnard, F., Gerber, A.E., Van der Westhuizen, G.J. \& Smit, R.J., 1978, Opvoedkunde vir onderwysstudente, Universiteitsuitgewers, Stellenbosch.
Linde, G., 2003, 'The use of two-dimensional models in Social Science: An auto critical review [Die gebruik van twee-dimensionele modelle in die Sosiale Wetenskappe: 'n Auto kritiese oorsig]', European Journal for Teacher Education 26(1), 37-45.

Louw-Carstens, M., 2012, '13-jarige steek seun met skêr', Beeld, 09 Maart, bl. 2.

Mouton, J., 2007, North-West University workshop of August 2007, North-West University, Potchefstroom.

Nel, P., 2012, 'God ons skuilplek van geborgenheid', ongepubliseerde artikel, Pretoria. Oosthuizen, I.J., 2007, Report on learner misconduct in the Kenneth Kaunda-district of North-West, North-West University, Potchefstroom.

Oosthuizen, I.J., 2011, 'Geborgenheid as 'n sine qua non vir die onderwys', in I.J. Oosthuizen (red.), J.P. Rossouw \& A. de Wet, Inleiding tot die onderwysreg, bl. 1, Van Schaik, Pretoria.

Organisation for Economic Co-operation and Development (OECD), 2009, Teaching and learning international survey, Staatsdrukker, Pretoria.

Postma, F., 1985, s.v. 'dissipline', Beknopte woordeboek: Latyn/Afrikaans, HAUM, Pretoria, bl. 93.

Pretorius, G., 2011, 'Kinders by die skool praat oor verkragte', Beeld, 22 Februarie, bl. 6 .

Prinsloo, J.G. \& Beckman, J.H., 1989, Die onderwyser en die regte en pligte van die kind, ouers en onderwysers, Lex Patria, Johannesburg.

Rademeyer, A., 2011, 'Dissipline in skole pootjie goeie onderrig', Beeld, 21 Desember, bl. 12.

Rademeyer, A., 2012a, 'Bullebakke gepos', Beeld, 22 Augustus, bl. 8.

Rademeyer, A., 2012b, 'Hoof in hof, nie kantoor', Beeld, 30 Augustus, bl. 1.

Renn, S.D., 2005, Expository dictionary of Bible words, Hendrickson Publishers, Peabody.

Roos, R., 2003, 'The legal nature of schools, codes of conduct and disciplinary proceedings in schools [Die regsaard van skole, gedragskodes en dissiplinêre verrigtinge in skole]', Koers - Bulletin for Christian Scholarship 68(4), 499-520.

Schoeman, P.G., 1978, 'Die onderlinge verhoudinge van onderwys in perspektief geplaas', in H.J.J. Bingle (red.), Besinning en verantwoording, ble. 68-84, Butterworth, Durban.

Schoonees, P.C., Toerien, M.F., Van Blerk, N., Wessels, A.C., Schoonees, F.J. \& Swanepoel, C.J., 1972, s.v. 'geborgenheid', Woordeboek van die Afrikaanse taal, Staatsdrukker, Pretoria, bl. 54.

Snyman, J., 2011, Education, South African Institute of Race Relations (SAIRR), Johannesburg.

Snyman, J., 2012, Education, South African Institute of Race Relations (SAIRR), Johannesburg

Snyman, J., 2013, Fast facts, South African Institute of Race Relations (SAIRR), Johannesburg.

South African Press Association (SAPA), 2012, 'Skolier doodgesteek', Beeld, 21 Maart, bl. 4 .

Strong, J., 1995, The new Strong's exhaustive concordance of the Bible, Thomas Nelson, Nashville.

Suid-Afrika, 1996a, Die Suid-Afrikaanse Grondwet, Wet 108 van 1996, Staatsdrukker, Pretoria.

Suid-Afrika, 1996b, Die Suid Afrikaanse Skolewet, Wet 84 van 1996, Staatsdrukker, Pretoria.

Suid-Afrika, 1998, Riglyne vir die oorweging van Beheerliggame by die aanvaarding van'n gedragskode vir leerlinge, Staatsdrukker, Pretoria.

Van der Walt, J.L. \& Dekker, E.I., 1983, Fundamentele Opvoedkunde vir onderwysstudente, Media publikasies, Silverton.

Van der Westhuizen, P.C., 1990, Doeltreffende onderwysbestuur, HAUM, Pretoria.

Van Loggerenberg, N.T. \& Jooste, A.J.C., 1980, Verantwoordelike opvoeding, Nasionale Boekhandel, Bloemfontein.

Van Zyl, P., 1975, Opvoedkunde, deel 2, Boekhandel De Jongh, Braamfontein

Vaughan, T., 1975, Geborgenheid as onderrigkriterium in die pedo-diagnostisering, Randse Afrikaanse Universiteit, Johannesburg.

Verenigde Nasies (VN), 1990, Convention on the Rights of the Child, United Nations, New York.

Versluis, J.M., 2011, 'Skolier buite skool beseer', Beeld, 16 Februarie, bl. 4.

Wolhuter, C.C., Oosthuizen I.J. \& Van Staden, J.G., 2010, 'Leerderouderdom as faktor in leerderdissipline in Suid-Afrikaanse skole', Tydskrif vir Christelike Wetenskap 46(1), 169-186.

Wolhuter, C.C. \& Steyn, H.J., 2003, 'Learner discipline at school: A comparative educational perspective [Leerderdissipline in skole:'n Vergelykend-opvoedkundige perspektief]', Koers - Bulletin for Christian Scholarship 68(4), 521-538.

Wondergem, H., 2011, 'Kind leef in vrees na boelie-aanval', Rapport, 26 Junie, bl. 10. 